VISNYK LVIV UNIV.

ерія геогр. 2011. ип. 39. . .72-77

Ser. Geogr. 2011. N 39. P. 72-77

624.131 .551 .3

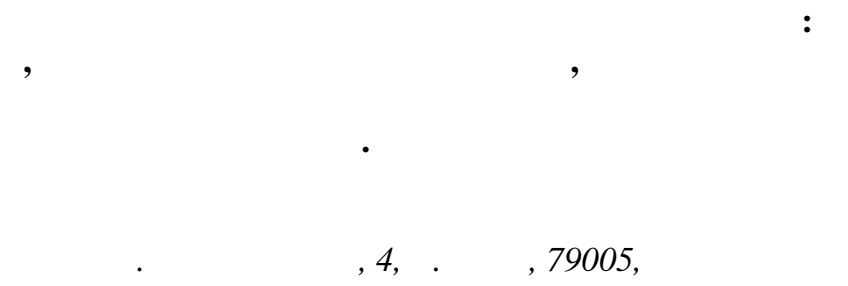

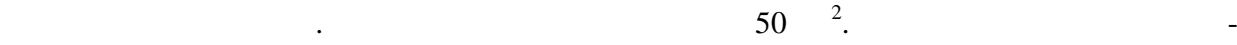
ного підтоплення приурочені до ьвівського пл то. риродне підтоплення прит м нне долин м річок і потоків. ильно розчленов ні ділянки озточчя н леж ть до непідтоплюв них. оловними природними чинник ми розвитку підтоплення є близьке від поверхні з ляг ння водотривких порід і вирівняний рельєФ, техногенними - витоки води з інженерних мереж т порушення поверхневого стоку.

лючові слов : підтоплення, техногенний водоносний горизонт, грунтові води, рельєф, водотривкі породи, культурний ш р, сейсмічність.

ор з більші м сшт би розвитку підтоплення урб нізов них територій, які спостеріг ють ост нні декільк десятків років, поступово перетворили його з процесу місцевого і регіон льного зн чення у н йбільш гостру і кту льну з г льнон ціон льну проблему.

ід терміном “підтоплення" розуміють підвищення рівня підземних вод бо утворення нового водоносного горизонту, які досяг ють критичних зн чень і потребують вжиття з хисних з ходів [4, 5 т ін.]. озрізняють підтоплення природне, зумовлене природними чинник ми, і техногенне - виклик не будівництвом т іншою господ рською діяльністю [ 6].

озвиток процесів підтоплення супроводжується з брудненням підземних вод, Ктивіз цією суч сних морфодин мічних процесів (зсувів, к рсту, суфозії тощо), зволоженням і з топленням з глиблених приміщень, зниженням несучої зд тності порід, тр нсформ цією і вторинним з соленням грунтів, змін ми видового скл ду, структури т продуктивності рослинного покриву, підвищенням сейсмічності територій.

о к тегорії підтоплених н леж ть території міст, н яких рівні грунтових вод постійно бо тимч сово перебув ють вище проектних норм осушення територій н селених пунктів, які ст новлять 2-5 м [7].

х р ктером виділяють декільк видів підтоплення: ст ле - коли рівень грунтових вод трив лий ч с з ляг є вище проектних норм осушення, періодичне - рівень грунтових вод перевищує норми осушення тимч сово (н прикл д сезонне підтоплення), прихов не - виявляється в зрост нні вологості грунтів до критичних зн чень (повного 3 повнення порового простору водою) вн слідок н копичення к пілярно піднятої, к пілярно підвішеної чи к пілярно з щемленої вологи. рім того, території міст поділяють н підтоплені, потенційно підтоплюв ні т непідтоплюв ні [6].

кр їні підтопленням охоплено близько 30 \% ії території, 540 міст і селищ міського типу $[1,4,7,9]$. озвиток цього процесу з вд є величезних економічних, соці льних

() олошин ., 2011 
т екологічних збитків і потребує грунтовних н укових досліджень. ро їхню в жливість т кту льність свідчить низк спеці льних держ вних прогр м, ре ліз ція яких спрямов н н суттєве зменшення м сшт бів розвитку цього процесу і мініміз цію з вд них збитків.

грудні 2010 р. іністерство житлово-комун льного господ рств 3 твердило оложення про систему моніторингу підтоплення міст і селищ міського типу кр їни, яким визн чено порядок збир ння, оброблення, перед в ння, збереження т форм ції щодо ст ну підтоплення міст і селищ міського типу, прогнозув ння його змін т розроблення н уково обгрунтов них рекоменд цій для прийняття рішень про 3 побіг ння нег тивним змін м ст ну довкілля т дотрим ння вимог екологічної безпеки.

о міст, де підтоплення з вд є чим лих екологічних т соці льно-економічних збитків, н лежить і ьвів. ей процес без перебільшення можн 3 лічити до н йбільш поширених н території міст . дн к н лежного н укового н лізу його досі нем .

ш мет - вивчення особливостей і з кономірностей розвитку підтоплення н території м. ьвов т оцінк його екологічних н слідків.

ля досягнення пост вленої мети вирішув ли т кі з вд ння:

- оцінюв ли вплив природних чинників н розвиток процесів підтоплення;

- виявляли основні техногенні джерел впливу н підземні води;

- вст новлюв ли просторові з кономірності розвитку підтоплення;

- оцінюв ли екологічні н слідки розвитку підтоплення.

нформ ційною б зою пр ці є результ ти польового обстеження окремих $\mathrm{p}$ йонів міст т ретроспективний н ліз д них свердловин, пробурених у різних $\mathrm{p}$ йон х міст в різний ч с.

собливості, м сшт би прояву процесу т його інтенсивність зн чно з леж ть від природних умов території, х р ктеру, інтенсивності й трив лості нтропогенного впливу н підземну гідросферу.

йбільші з площею ре ли техногенного підтоплення приурочені до центр льної, 3 хідної т північно-з хідної ч стини ьвівського пл то, які м ють н йбільш сприятливі природні умови для його розвитку т потужне нтропогенне н в нт ження н геологічне середовище.

меж х пл то до глибини 6-10 м з ляг є товщ сл бкофільтрув льних, дегр дов них лесових суглинків, м йже повсюдно підстелених водотривкими глин ми верхнього б денію. езн чн дренов ність території, фільтр ційн нізотропія лесів, н явність у них викопних грунтів, зн чне поширення блюдцеподібних з п дин т к рстових лійок в умов х н дмірного тмосферного зволоження сприяли досить високому (3-6 м) природному з ляг нню грунтових вод.

жливу роль у розвитку техногенного підтоплення цього $\mathrm{p}$ йону відігр ють численні штучні водоймищ, утворені н місці глиняних к р'єрів, існув ння яких відоме ще $з$ кінця $\mathrm{V}$-поч тку $\mathrm{V}$ ст. н чн кількість к р'єрів, у яких у 60-70-х рок х видобув ли лесові суглинки для виробництв цегли, у вигляді штучних водоймищ різного розміру існують дотепер. о них н леж ть великі (2-4 г ) штучні водоймищ в p йоні цегельного з воду н вулицях трийській, росл ви узики т ін.

сшт бне містобудівне освоєння цієї території, яке розпоч лося у 70-х рок х

ст., призвело до зн чних змін умов поверхневого стоку т порушення природного водного б л нсу території, зумовленого великими втр т ми води з водоносних мереж. езульт том цього ст в розвиток процесів техногенного підтоплення. н слідок неконт- 
рольов ного піднім ння рівнів грунтових вод суттєво погіршилися с ніт рно-гігієнічні умови експлу т ції підв льних приміщень у житлових будинк х, виникли проблеми використ ння технологічних уст новок промислових підприємств.

орушення природної гідродин мічної рівнов ги, зумовлені процес ми підтоплення, створили ре льну з грозу перетік ння гресивних вод четвертинного горизонту у гіпсовий м сив і ктивіз ції сульф тного к рсту н цій території.

н чне погіршення екологічної ситу ції спостеріг ють т кож н з будов них схил х ьвівського пл то. н слідок формув ння техногенного водоносного горизонту і перезволоження лесових грунтів виник ють нтропогенно зумовлені зсуви. ідвищується сейсмічність території. піщ них грунт х розвив ються процеси мех нічної суфозії, які суттєво понижують стійкість схилів. ерезволоження лесових супісків н пр вому схилі улецького потоку спровокув ло великий зсув н вул. х ров .

меж х цього геоморфологічного р йону підтоплен зн чн кількість житлових будинків т промислових об'єктів. еред них - ьвівський кер мічний з вод, івівміськбуд, ьвівобленерго т б г то інших.

томість східн т північно-східн, н йбільш розчленов н , добре дренов н , скл ден піск ми ч стин пл то н лежить до к тегорії непідтоплюв них. кими $є$ т кож ьвівське озточчя, яке 3 йм $є$ північну т ч стково північно-з хідну ч стину міст . ей геоморфологічний р йон м є несприятливі для розвитку підтоплення рель$€ ф$, геолого-гідрогеологічні умови т незн чну господ рську освоєність.

собливого зн чення розвиток процесів підтоплення н був $є$ в меж х історичної 3 будови ьвов , з несеної до списку всесвітньої сп дщини — я ч стин міст , як відомо, розт шов н у ьвівській улоговині, приуроченій до з пл ви р. олтви т ії допливів.

гідрогеологічній будові цієї ділянки беруть уч сть дв водоносні горизонти: четвертинних і верхньокрейдових відкл дів.

етвертинний водоносний горизонт поширений лок льно. ін простежений лише в меж х днищ улоговини (з пл ви р. олтви). тї схил х води повністю здренов ні. ерхньокрейдовий - поширений н всій території. ін приурочений до тріщинув тих мергелів верхньої крейди. ід четвертинних вод відділений товщею мергелистих глин потужністю від 0,7 до 12,0 м.

р ктерною особливістю цієї ч стини міст є докорінн змін всього природного комплексу: геологічного середовищ, рельєфу, гідрогр фічної мережі, грунтово-рослинного покриву, мікроклім ту, т кож високий рівень техногенного покриття поверхні. ум рн площ ділянок під будівлями, вуличним покриттям, з мощеними двор ми, спортивними м йд нчик ми тощо досяг є 81,5\%. риродн поверхня перебув є під техногенним покривом, який сприяе конденс ції вологи. інім льний нтропогенний покрив фіксують у п рку ім. в н пекту вободи, сквері н уберн торських в л х (вул. ідв льн ).

жливим компонентом нтропогенного н в нт ження є водоносні мережі. ум pн довжин лише м гістр льних к н ліз ційних колекторів досяг є тут 20,5 км, водогонів - 57 км. усло р. олтви т їі допливів (р. іл , потік ртиш), які були природними дрен ми, повністю к н лізов ні.

тр ти води лише з водогонів досяг ють 1,2 тис. м 3 добу н $1 \mathrm{kм}^{2}$. д ними водок н лу тут щорічно виник є до 100 в рійних ситу цій н водогон х т к н ліз ційних мереж $\mathrm{x}$. 
роцеси підтоплення н цій ділянці виявляються у вигляді зн чної кількості ізольов них куполів техногенних вод, розт шов них н схил х полтвинської улоговини, де природних вод нем , т суцільного водоносного горизонту, приуроченого до з пл вної тер си р. олтви. ум рн площ підтоплених ділянок у цьому р йоні міст сяг є 47 г, що ст новить 23,4 \% від його з г льної площі.

либин з ляг ння техногенного водоносного горизонту тут колив ється від 1,2 2,0 до 3,5-4,5 м. ого потужність, з звич й, невелик, пересічно вон не перевищує 1,5-2,0 м і лише в окремих вип дк х досяг є 3,5 м.

оди техногенного водоносного горизонту м ють зн чний ступінь нтропогенного мет морфізму. хня мінер ліз ція н окремих ділянк х досяг є 5-8 і н віть 13,6 г/л [2].

пеці льними дослідженнями, які пров дили у центр льній ч стині ьвов , про н лізов но в рійні ситу ції, що тр пилися 3 ост нні вісім років. 'ясов но, що 3 цей проміжок ч су н території площею близько $2 \mathrm{kм}^{2}$ ст лося 794 в рії. ісля н несення їх н к рту виявилося, що ч сто вони виник ли в одних і тих же місцях. е д ло змогу пов'язув ти повторення в рій з ділянк ми інтенсивного осід ння земної поверхні, зумовленого нерівномірним ущільненням грунтів культурного ш ру. трим ні д ні д ють підст ву стверджув ти, що в рійність водоносних мереж у центрі ьвов зн чно пов'яз н не лише з їхньою н дмірною зношеністю, й нерівномірним осід нням земної поверхні.

ктивний розвиток процесів підтоплення в центр льній ч стині міст супроводжується погіршенням с ніт рно-гігієнічних умов експлу т ції к фе, рестор нів, музеїв тощо, розт шов них у підв льних ч стин х будівель. цьому р зі відбув ється перезволоження стін, відш рув ння т руйнув ння тиньку, з солення і руйнув ння будівельного к меню, поширення грибк . ктивне руйнув ння будівельного к меню відбув ється вн слідок крист ліз ції техногенних мінер лів.

д ними рентгеноморфологічного н лізу, новоутворені мінер ли предст влені головно сульф т ми н трію з різною кількістю молекул води. ровідну роль серед них відігр є безводний сульф т н трію - тен рдит $\left(\mathrm{Na}_{2} \mathrm{SO}_{4}\right)$. незн чній кількості тр пляються в нтгофіт, гіпс т левеїт. ідвищений вміст техногенних мінер лів свідчить про к пілярне підсмоктув ння техногенних вод, зб г чених сульф т ми ін трієм.

исоли новоутворених мінер лів виявлені н стін х підтоплених підв лів туші,

л цу ндинеллі н пл. инок, 2, житловому будинку н пл. инок, 25, 27, пр. вободи 24, пр. евченк , 10, універм зі н вул. евській,1, вул. ербській 5, 10, н тюк , 2 т 6 г тьох інших.

д ними гідрогеологічного моніторингу, у центрі міст є тенденція поступового підняття рівня грунтових вод. видкість його підійм ння по окремих свердловин х колив ється від 1-3 до $13 \mathrm{~cm} /$ рік. йбільше ї̈ зн чення з фіксов но у р йоні вул. овжун . цій ділянці т кож н йвищ швидкість осід ння земної поверхні, як досяг $є$ тут 1 см 3 рік [3] і сприяє прискореному руйнув нню водоносних мереж т високим обсяг м втр т води.

н чні м сшт би підтоплення з фіксов но т кож н окремих ділянк $\mathrm{x}$ височини озточчя, зокрем , у івнічному пл нув льному р йоні міст . ля цього р йону х $\mathrm{p} \mathrm{K-}$ терне близьке від поверхні (3-5 м) з ляг ння верхньокрейдових мергелів т кори їхнього звітрюв ння, скл деної водотривкими мергелистими глин ми. о містобудівного освоєння грунтових вод тут не було. сові витоки води з інженерних мереж упродовж ост нніх десяти років, порушення природних умов поверхневого стоку призвели до ктивного розвитку процесів підтоплення. ині н б г тьох ділянк х (вул. етьм н 
зепи, илип рлик т ін.) сформув вся техногенний водоносний горизонт, рівень якого в окремих місцях є н глибині 0,5-1,0 м від поверхні землі. изк житлових і соці льно-культурних об'єктів виявил ся підтопленою. ерівномірне зволоження лесових грунтів і зниження їхньої несучої зд тності призводить до недопустимих деформ цій окремих будівель і споруд.

йбільші з площею ре ли постійного природного підтоплення спостеріг ють у меж х розлогих, плоскодонних, з б гнених долин ілогірського, ев ндівського, уднянського т яснянського потоків. ут з огляду н дуже пог ну дренов ність території грунтові води з ляг ють н глибин х від 0,0 до 1-2 м. н логічн ситу ція прит м нн міжп смовим долин м лого олісся т днищ м долин пр ктично усіх річок ( убр, руньк, сік ) і потоків ( окільницького, улецького, имноводського т iH.).

ериторії, у меж х лесових п сом лого олісся ( лехівське, инниківське) н леж ть до потенційно підтоплюв них. они скл дені досить потужними лесовими товщ ми, які з ляг ють н мергелях верхньої крейди. есові п чки вміщують декільк горизонтів викопних грунтів, які відігр ють роль тимч сових водотривких ш рів. рім того, для лесів х р ктерн чітко вир жен фільтр ційн нізотропія. они добре пропуск ють воду у вертик льному н прямі й пог но - у горизонт льному, що сприяє розвитку процесів підтоплення. ьогодні без нтропогенного н в нТ ження, зн чного вертик льного і горизонт льного розчленув ння ці ділянки не підтоплюються. томість у p зі ктивного господ рського освоєння, порушення природного поверхневого стоку вони будуть ктивно з зн в ти підтоплення. скр вим прикл дом природного підтоплення лесових м сивів є північн , вирівнян ч стин инниківського п см (сел исиничі, ідбірці). он з вдяки вирівняному рельєфу і пог ному відтоку тмосферних вод н лежить до к тегорії природно підтоплених. 䛠 меж х грунтові води з ляг ють н глибині 1-2 м.

орієнтовними підр хунк ми сум рн площ природно і техногенно підтоплених ділянок н території міст перевищує $50 \mathrm{~km}^{2}$. езв ж ючи н широкий спектр нег тивних екологічних н слідків розвитку процесів техногенного підтоплення теритоpiї м. ьвов , вони н леж ть до н йменш вивчених.

ля ост точного з'ясув ння м сшт бів підтоплення території міст , особливо техногенного, треб провести п спортиз цію всіх господ рських об'єктів. кр й в жливою і кту льною проблемою, що потребує н г льного вирішення, є створення системи моніторингу підтоплених і потенційно підтоплюв них територій, як є інформ ційною б зою для прогнозу підтоплення т розробки н уково обгрунтов них з ходів з ліквід ції його н слідків.

дним 3 н йдієвіших способів 3 побіг ння т боротьби з підтопленням є суттєве зменшення обсягів водовтр т з водоносних мереж - основної причини порушення водного б л нсу н території міст .

1. биченко . ., еб нов . ., икитенко . ., уніхін . . уч сні проблеми підтоплення міст і селищ міського типу в кр їні, шляхи їх вирішення // існик кр. будинку економ. т н ук.-техн. зн нь. № 9. . : : 1998. . 3-12.

2. олошин . ., конечний . ., льченко . . кологічний ст н вод підземної гідросфери історичної з будови ьвов // еоінформ тик . 2003. № 2. . 93-98. 
3. олошин . . риродно- нтропогенні деформ ції земної поверхні урб нізов них територій як пок зник геодин мічного ризику // еодезія, к ртогр фія і ерофотознім ння. ьвів, 2002. . 14-20. 4. олошкін . ., озмет ев . ., еб нов . ., ковлев . . ідтоплення. кологічн енциклопедія. . . 3. ., $2008 . \quad$. 98.

5. бстеження т облік підтоплених міст і селищ: методичні рекоменд ції / з ред. . . емчук . рків, 2004. $54 \mathrm{c}$.

6. рогноз и предотвр щение подтопления грунтовыми вод ми территорий при строительстве. . : тройизд т, 1978. $177 \mathrm{c}$.

7. и 2.06.15-85. нженерн я з щит территорий от з топления и подтопления. ., осстроя, 1986. $20 \mathrm{c}$.

8. тріжельчик . . ідтоплення н селених пунктів. кологічн енциклопедія. . 3. ., 2008. $.98-99$.

9. трижельчик . ., околов . ., ольдфельд . ., еб нов . ., икол енко . . одтопление в н селенных пункт х рьковской обл сти. рьков, 2003. 159 с.

\title{
THE FLOODING OF LVIV TERRITORY: REASONS, PATTERNS OF DEVELOPMENT, ECOLOGICAL CONSEQUENCES
}

\author{
P. Voloshyn \\ Ivan Franko National University of Lviv, \\ P. Doroshenko St., 41, UA - 79000 Lviv, Ukraine
}

Flooding territories of Lviv occupy area more than $50 \mathrm{~km}^{2}$. The largest area of technogenic flooding belongs to Lviv plateau. Highly dissected parts of Roztochchya belong to nonflooding. Main nature reasons of flooding development are near to surface occurrence waterproof deposits and leveled relief. Technogenic flooding are outflows of water from engineer networks and infraction of surface water.

Key words: flooding, technogenic aquifer, soil waters, waterproof deposits, cultural layer, seismicity.

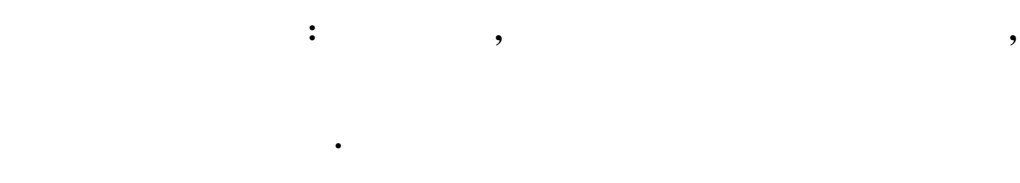

ьвовский н цион льный университет имени в н

ул. . орошенко, 41, г. ьвов, 79000, кр ин

одтопленные территории в г. ьвове з ним ют площ дь более $50 \mathrm{kм}^{2}$. ибольшие ре лы техногенного подтопления приурочены к ьвовскому пл то. риродное подтопление свойственно долин м рек и ручьев. ильно р счлененные уч стки сточья относятся к неподтопляемым. л вными природными ф ктор ми р звития подтопления есть близкое от поверхности з лег ние водоупорных пород и выровненный рельеф, техногенными - утечки воды с инженерных сетей и н рушение поверхностного сток .

лючевые слов : подтопление, техногенный водоносный горизонт, грунтовые воды, рельеф, водоупорные породы, культурный слой, сейсмичность.

т ття н дійшл до редколегії 18.02.2011 рийнят до друку 19.04.2011 